\title{
AnNa RedA
}

Uniwersytet Kardynała Stefana Wyszyńskiego

\section{PRACA TYMCZASOWA W ŚWIETLE PRAWA WSPÓLNOTOWEGO}

\section{UWAGI WSTĘPNE}

Praca tymczasowa dotychczas nie doczekała się całościowego i wyczerpującego unormowania w prawie wspólnotowym pomimo, iż podjętych zostało wiele prób w tym celu. Zagadnienie to jednak pozostaje nadal aktualne $\mathrm{z}$ uwagi na inicjatywę Prezydencji portugalskiej, która we wrześniu 2007 roku wznowiła pracę nad zmienionym projektem dyrektywy Parlamentu Europejskiego i Rady w sprawie warunków pracy pracowników tymczasowych z dnia 28 lipca 2002 roku$^{1}$. Dotychczas praca tymczasowa została objęta w prawie wspólnotowym regulacją dyrektywy 91/383 z 25 czerwca 1991 r. uzupełniającej działania mające na celu poprawę bezpieczeństwa i ochrony zdrowia w miejscu pracy pracowników zatrudnionych na podstawie umowy o pracę na czas określony lub poprzez agencję pracy tymczasowej ${ }^{2}$ oraz dyrektywy 96/71 z 16 grudnia 1996 r. dotyczącej kierowania pracowników

${ }^{1}$ COM 2002 (701) final.

${ }^{2}$ Dyrektywa Rady 91/383/EWG z dnia 25 czerwca 1991 r. uzupełniająca działania mające na celu poprawę bezpieczeństwa i ochrony zdrowia w miejscu pracy pracowników zatrudnionych na podstawie umowy o pracę na czas określony lub na podstawie stosunku pracy tymczasowej, Dz. Urz. WE, Nr L 2006 z 29 lipca $1991 \mathrm{r}$. 
do pracy za granicę w ramach świadczenia usług³ . Głównym przedmiotem opracowania będzie kwestia wprowadzenia regulacji o charakterze kompleksowym w nawiązaniu do obowiązujących już aktów, ale normujących w pewnym jedynie fragmencie zjawisko pracy tymczasowej w prawie wspólnotowym.

Nie ulega wątpliwości, iż normy unijne z zakresu prawa pracy mają zdecydowanie węższy zakres niż prawo pracy obowiązujące w poszczególnych państwach członkowskich ${ }^{4}$. Znaczenie i rolę prawa wspólnotowego po wejściu Polski do Unii Europejskiej należy jednak podkreślić z uwagi na konieczność zapewnienia zgodności prawa krajowego z prawem wspólnotowym, a w razie kolizji lub niejasności norm obowiązek stosowania wykładni prawa krajowego w zgodzie z prawem wspólnotowym $^{5}$. Wśród źródeł wspólnotowego prawa pracy dominują dyrektywy ${ }^{6}$. Wspólnota Europejska nie ma ogólnej kompetencji do stanowienia prawa pracy. Przedmiotem prawa wspólnotowego mogą być tylko kwestie wyraźnie wskazane w traktatach ${ }^{7}$. Z zakresu przedmiotu regulacji prawa wspólnotowego zostały wprost wyłączone następujące zagadnienia: wynagrodzenia, prawo zrzeszania się, prawo do strajku i lokautu (art. 137 ust 6 TWE). Dyrektywy należą do wtórnego wiążącego prawa wspólnotowego obok: aktów prawa pierwotnego oraz aktów prawa wtórnego wiążącego: rozporządzeń i decyzji oraz aktów prawa wtórnego niewiążącego: zalecenia, opinie. W myśl art. 249 Traktatu o ustanowieniu Wspólnoty Europejskiej dyrektywa wiąże państwo członkowie, do któ-

${ }^{3}$ Dyrektywa Parlamentu Europejskiego i Rady 96/71/WE z dnia 16 grudnia 1996 r. dotycząca kierowania pracowników do pracy za granicę w ramach świadczenia usług, Dz. Urz. WE nr L 018 z 21 stycznia 1997 r.

${ }^{4}$ I. Boruta, Polityka społeczna, zatrudnienie, edukacja, szkolenie, młodziez, [w:] Prawo Unii Europejskiej. Prawo materialne i Polityki, red. J. BARCz, Warszawa 2003, s. 378 .

${ }^{5}$ L. FloreK, Znaczenie wspólnotowego prawa pracy, «PiZS» 2004 nr 5, s. 3.

${ }^{6}$ I. Boruta, Dyrektywy Wspólnoty Europejskiej jako źródło prawa pracy w Polsce, «PiZS» $2005 \mathrm{nr} 5$, s. 2; TEJżE, Źródła prawa pracy w Polsce po przystapieniu do Unii Europejskiej, «Kwartalnik Prawa Publicznego» 4.2 (2004), s. 127.

${ }^{7}$ Z. Hajn, Specyficzne cechy i problemy stosowania europejskiego prawa pracy, Łódź 2006, s. 2. 
rego jest kierowana, w odniesieniu do rezultatu, który ma być osiagnięty, pozostawia organom krajowym swobodę wyboru formy i środków. Implementacja dyrektywy może nastapić także na podstawie art. 137 ust. 3 Traktatu WE, który stanowi, że dyrektywy z zakresu prawa pracy mogą być wprowadzone w życie przez partnerów społecznych, czyli przedstawicieli pracowników i pracodawców poprzez zawarcie stosownych układów zbiorowych pracy lub porozumień ${ }^{8}$.

$\mathrm{Na}$ gruncie prawa wspólnotowego praca tymczasowa, obok zatrudnienia terminowego oraz zatrudnienia $\mathrm{w}$ niepełnym wymiarze czasu pracy, jest zaliczana do kategorii atypowych form zatrudnienia ${ }^{9}$ Pojęcia praca atypowa i praca (zatrudnienie) nietypowa bywają używane w piśmiennictwie wymiennie. Należy jednak podkreślić, że nie są to pojęcia tożsame. Przyjmuje się, że praca atypowa jest pojęciem węższym i zawierającym się $\mathrm{w}$ zakresie pojęcia zatrudnienia nietypowego. Według T. Zielińskiego praca atypowa to ,praca w rozumieniu skodyfikowanego prawa pracy, ale nietypowa w tym znaczeniu, że jest wykonywana w sposób częściowo inny niż praca odpowiadająca ogólnym, powszechnie stosowanym regułom" ${ }^{10}$. Posługując się tą definicją należy dojść do wniosku, iż zatrudnienie atypowe będzie mieścić się w pojęciu zatrudnienia nietypowego jako pojęcia bardziej obszernego. Nietypowe formy zatrudnienia to nowe formy zatrudnienia w ramach których wskazuje się obok zatrudnienia o charakterze pracowniczym, także zatrudnienie o charakterze niepracowniczym.

Promocja zatrudnienia nietypowego stanowi element Europejskiej Strategii Zatrudnienia ${ }^{11}$. Zgodnie $\mathrm{z}$ formuła przyjętą na szczycie

${ }^{8}$ Por. A.M. ŚwiątKowski, Implementacja wspólnotowego prawa pracy przez partnerów społecznych, [w:] Prawo pracy a wyzwania XXI wieku, Księga Jubileuszowa Prof. T. Zielińskiego, red. M. Matey-Tyrowicz, Warszawa 2002, s. 625.

${ }^{9}$ Z. Kuвот, Prawo pracy, Zarys wykładu, Warszawa 2005, s. 71.

${ }^{10}$ T. ZIELIŃSKI, Umowy o zatrudnienie, [w:] Szczególne formy zatrudnienia, red. Z. Кивот, Wrocław 2000, s. 61.

${ }^{11}$ Por. E. Casado Alarcon, Agency Work in the European Union, [w:] Temporary Agency Work and Information Society, ed. R. Blanpain, R. Graham, Kluwer International Law, Hague/London/New York 2004, s. 304. 
w Lizbonie w 2000 r. gospodarka Unii Europejskiej ma stać się najbardziej konkurencyjną i dynamiczną gospodarką opartą na wiedzy zdolną do trwałego i zrównoważonego rozwoju oraz tworzenia więcej pracy lepszej jakości w warunkach spójności społecznej. Założeniem europejskiej strategii zatrudnienia jest połączenie elastyczności i bezpieczeństwa w zatrudnieniu tzw. koncepcja flexicurity (flexisecurity $)^{12}$. Koncepcja flexicurity zakłada doprowadzenie do osiagnięcia w przyszłości wysokiego wskaźnika zatrudnienia i zmniejszenia wskaźnika bezrobocia w UE przy jednoczesnym zachowaniu wysokiego standardu ochrony zatrudnienia na podstawie stosunku pracy ${ }^{13}$. W związku z przyjętą koncepcją w wielu dokumentach unijnych pojawia się wezwanie do promowania tzw. nietypowych form zatrudnienia (atypowych) przy zapewnieniu pracownikom wysokiego standardu ochrony.

W Agendzie Społecznej z 2000 r. stanowi się o zrównoważonym rozwoju gospodarczym i społecznym. Z tą deklaracją wiąże się niewątpliwie koncepcja „flexicurity” polegająca na wprowadzeniu nowej równowagi pomiędzy elastycznością a ochroną pracownika ${ }^{14}$. Można jednak zauważyć, iż praca tymczasowa jest zagadnieniem na tle którego koncepcja połączenia bezpieczeństwa i elastyczności w zatrudnieniu wydaje się być niemożliwa. Właśnie za przyczynę braku porozumienia uznawane są trudności w odnalezieniu równowagi pomiędzy tymi dwiema wartościami ${ }^{15}$.

${ }^{12}$ I. BorutA, Polityka spoleczna, zatrudnienie, cit., s. 376; TEJżE, Strategie zatrudnienia organizacji międzynarodowych, UE, MOP, OECD, Warszawa 2002, s. 8.

${ }^{13}$ Według komunikatu w sprawie „Wspólnych zasad wdrażania modelu flexisecurity" Komisji Europejskiej z dnia 27 czerwca 2007 r. COM (2007) 359 final, flexicurity określić można jako zintegrowaną strategię równoczesnego zwiększania elastyczności i bezpieczeństwa rynku pracy, na którą składają się cztery elementy: elastyczne i przewidywalne warunki umów, strategia uczenia się przez całe życie, aktywna polityka rynku pracy oraz nowoczesne systemy zabezpieczenia społecznego.

${ }^{14}$ I. BorutA, Zwiqzanie Polski standardami Społecznymi Unii Europejskiej, «Studia Prawno- Europejskie») 6 (2002), s. 175.

${ }^{15}$ P. KoRzyŃsKi, Agencyjna praca tymczasowa: regulacje unijne, «Zarządzanie Zasobami Ludzkimi» 2005 nr 3-4, s. 65. 
Problem w zakresie wprowadzenia całościowego unormowania dotyczącego pracy tymczasowej został odnotowany w opublikowanej w ostatnim czasie przez Komisję Europejską zielonej księdze zatytułowanej ,Modernizacja prawa pracy w celu sprostania wyzwaniom XII wieku" zapowiadającej debatę na temat przeprowadzenia reformy prawa pracy w Unii Europejskiej w przyszłości ${ }^{16} \mathrm{~W}$ toku konsultacji państwa członkowskie i partnerzy społeczni potwierdzili chęć wprowadzenia dyrektywy w zakresie pracy tymczasowej. Podjęcie działań w zakresie wprowadzenia regulacji zostało uznane za działania o charakterze pilnym i priorytetowym $w$ ramach modernizacji prawa pracy ${ }^{17}$.

\section{DOTYCHCZASOWE PRÓBY WPROWADZENIA UNORMOWANIA W ZAKRESIE} PRACY TYMCZASOWEJ W PRAWIE WSPÓLNOTOWYM

Praca tymczasowa jest instytucją normowaną w prawie wspólnotowym w sposób niepełny, a próby wprowadzenia całościowego unormowania mają już swoją historię. Pierwszy projekt dyrektywy, którego przedmiotem była instytucja pracy tymczasowej pochodzi z początku lat osiemdziesiątych XX w. W 1980 r. przyjęto rezolucję stwierdzająca potrzebę wspólnotowej regulacji pracy tymczasowej, której następstwem było przedstawienie projektu dyrektywy w 1982 r., a następnie poprawionego projektu z dnia 6 kwietnia 1984 r. ostatecznie jednak odrzuconego ${ }^{18}$. Projekt określał zasady użyczania pracowników, a jego celem było zapewnienie ochrony pracującym w ramach zatrudnienia tymczasowego poprzez zrównanie ich statusu ze statusem zatrudnionych na stałe. Projekt ten był oparty na rozwiązaniach prawa francuskiego i belgijskiego, według którego podstawą zatrud-

${ }^{16}$ COM (2006) 708 final.

${ }^{17}$ Komunikat Komisji Europejskiej do Rady, Parlamentu Europejskiego, Europejskiego Komitetu Ekonomiczno-Społecznego oraz Komitetu Regionów Wyniki publicznych konsultacji w sprawie zielonej księgi Komisji „Modernizacja prawa pracy w celu sprostaniu wyzwaniom XXI wieku", COM (2007) 627 final.

${ }^{18}$ M. MateY-Tyrowicz, Nietypowe formy zatrudnienia - dyrektywy i praktyka UE, [w:] Deregulacja polskiego rynku pracy, red. K.W. FrISKE, Warszawa 2003, s. 160. 
nienia pracownika tymczasowego była umowa terminowa ${ }^{19}$. Pierwszy projekt dyrektywy stał na stanowisku ograniczania dopuszczalności stosowania pracy tymczasowej do przypadków, w których zachodziła konieczność przejściowego lub spowodowanego nadzwyczajnymi okolicznościami wzrostu zapotrzebowania na pracę ${ }^{20}$. Należy podkreślić, iż już w tamtym czasie zauważono mniej korzystną sytuację pracownika tymczasowego $\mathrm{w}$ porównaniu do sytuacji pracowników stałych w zakresie wysokości wynagrodzenia pracownika tymczasowego, bezpieczeństwa i higieny w pracy oraz prawa koalicji.

Kolejna próba wprowadzenia odrębnej regulacji pracy tymczasowej została podjęta w latach dziewięćdziesiątych. W dniu 9 czerwca 1990 r. Komisja Europejska opublikowała trzy projekty dyrektyw: projekt dotyczący zbliżenia ustawodawstwa państw członkowskich w dziedzinie niektórych stosunków pracy w zakresie warunków pracy (tzw. stosunki pracy atypowej) oraz projekt w dziedzinie zakłóceń konkurencyjności ${ }^{21}$. Trzeci projekt dotyczył środków poprawy bezpieczeństwa i ochrony zdrowia pracowników zatrudnionych na czas określony i przez agencje pracy tymczasowej i został ostatecznie przyjęty jako dyrektywa Rady 91/38322. Celem wprowadzenia powyższych regulacji było wykonanie postanowień Wspólnotowej Karty Podstawowych Praw Socjalnych Pracowników przyjętej w Strasburgu w grudniu 1989 r. Należy zauważyć, iż spośród trzech projektów dyrektyw dotyczących pracy atypowej tylko projekt, który został oparty na procedurze opisanej w art. 118a Traktatu EWG, przewidującej wymóg większość kwalifikowaną głosów, został uchwalony.

${ }^{19}$ H. Szurgacz, Stosunki pracy z użyczeniem (przekazaniem) pracownika, [w:] Szczególne formy zatrudnienia, red. Z. Кивот, Wrocław 2000, s. 71-72.

${ }^{20}$ H. SzURGaCZ, op. cit., s. 72.

${ }^{21}$ Dz.Urz. WE, Nr C 224/90, s. 6.

${ }^{22}$ Dyrektywa Rady 91/383/EWG z dnia 25 czerwca 1991 r. uzupełniająca działania mające na celu poprawę bezpieczeństwa i ochrony zdrowia w miejscu pracy pracowników zatrudnionych na podstawie umowy o pracę na czas określony lub na podstawie stosunku pracy tymczasowej, Dz.Urz. WE, Nr L 2006 z 29 lipca 1991 r. 
W prawie wspólnotowym dopuszczalne jest wprowadzenie regulacji w odpowiednich porozumieniach ramowych zawartych przez partnerów społecznych działających na szczeblu wspólnotowym. W połowie lat dziewięćdziesiątych Komisja Europejska w celu wprowadzenia regulacji pracy tymczasowej uruchomiła konsultacje partnerów społecznych w celu zawarcia porozumienia społecznego, któremu następnie nadana miała zostać ranga dyrektywy wspólnotowej. Na początku następowało to na podstawie Porozumienia w sprawie polityki socjalnej zawartego 1 lutego 1992 r. w Maastricht pomiędzy państwami członkowskimi Wspólnoty, z wyłączeniem Zjednoczonego Królestwa Wielkiej Brytanii i Irlandii Północnej. Porozumienie stało się załącznikiem do Protokołu nr 14 z 7 lutego 1992 r. w sprawie polityki socjalnej, stanowiącego załącznik do Traktatu z Maastricht. Na podstawie tego porozumienia państwa członkowskie postanowiły, iż będą prowadzić bardziej postępową politykę społeczną ${ }^{23}$. Zgodnie $\mathrm{z}$ art. 4 ust. 2 porozumienia pracodawcy i pracownicy mogli występować ze wspólnym wnioskiem do Komisji Europejskiej o wprowadzenie $\mathrm{w}$ życie porozumień zawartych na szczeblu wspólnotowym w drodze decyzji Rady w formie dyrektywy. Traktat z Maastricht zagwarantował partnerom społecznym udział $\mathrm{w}$ procesie stanowienia prawa wspólnotowego oraz możliwość zawierania układów zbiorowych na szczeblu ponadnarodowym. W trybie określonym w art. 139 TWE dopuszczalne jest zawarcie porozumienia zbiorowego przez europejskich partnerów społecznych i następnie, na ich żądanie, wykonanie w drodze dyrektywy Rady UE na wniosek Komisji ${ }^{24}$. W wyniku tej procedury doszło do zawarcia porozumienia $\mathrm{m}$. in. w sprawie pracy na czas określony ${ }^{25}$ oraz pracy $\mathrm{w}$ niepełnym wymiarze czasu

${ }^{23}$ R. Blanpain, M. Matey, Europejskie prawo pracy w polskiej perspektywie, Warszawa 1993, s. 66; M. TomAszEWSKA, Indywidualne prawo pracy Unii Europejskiej, [w:] Zatrudnienie i ochrona socjalna, red. Z. BRODECKI, Warszawa 2004, s. 154.

${ }^{24}$ L. MITRUS, Wpływ regulacji wspólnotowych na polskie prawo pracy, 2006, s. $68 \mathrm{i} \mathrm{n.}$

${ }^{25}$ Dyrektywa Rady nr 99/70/WE z dnia 28 czerwca 1999 r. dotycząca porozumienia ramowego $\mathrm{w}$ sprawie pracy na czas określony, zawartego przez Europejską Unię Konfederacji Przemysłowych i Pracodawców (UNICE), Europejskie Centrum 
pracy $^{26}$. W wyniku tej procedury podjęte zostały również zakończone niepowodzeniem negocjacje w celu wprowadzenia odpowiedniej regulacji w zakresie pracy tymczasowej. Porozumienie zawarte przez partnerów społecznych może zostać wykonane zgodnie z procedurami i praktykami właściwymi dla partnerów społecznych i Państw Członkowskich ${ }^{27}$.

W literaturze podkreśla się, że liczba wprowadzonych unormowań dotyczących tzw. niestandardowych form zatrudnienia jest uzależniona od porozumień partnerów społecznych w tym zakresie ${ }^{28}$. Podkreśla się, iż Rada m.in. w wytycznych z 14 II 2000 r. odwołuje się nie do dialogu społecznego, a do partnerstwa pomiędzy pracownikami a pracodawcami. Podejście to ma na celu wymuszenie na związkach zawodowych akceptacji coraz bardziej powszechnych form nietypowego zatrudnienia $^{29}$. W tym właśnie trybie wprowadzono do prawa wspólnotowego unormowanie $\mathrm{w}$ zakresie pracy $\mathrm{w}$ niepełnym wymiarze czasu pracy oraz pracy na czas nieokreślony. W preambule dyrektywy dotyczącej pracy na czas określony wskazywano jednak na konieczność wprowadzenia odrębnego i całościowego uregulowania w odniesieniu do pracowników tymczasowych.

W maju 2000 r. partnerzy społeczni podjęli negocjacje, które miały doprowadzić do zawarcia porozumienia w sprawie pracy tymczasowej. Jednakże partnerzy społeczni w dniu 21 maja 2001 roku przyznali,

Przedsiębiorstw Publicznych (CEEP), Europejską Konfederacje Związków Zawodowych (ETUC), Dz. Urz. WE nr L 175 z 10 lipca 1999 r.

${ }^{26}$ Dyrektywa Rady nr 97/81/WE z dnia 15 grudnia 1997 r. dotycząca porozumienia ramowego dotyczącego pracy $\mathrm{w}$ niepełnym wymiarze godzin zawartego przez zawartego przez Europejską Unię Konfederacji Przemysłowych i Pracodawców (UNICE), Europejskie Centrum Przedsiębiorstw Publicznych (CEEP), Europejską Konfederacje Związków Zawodowych (ETUC), Dz. Urz. WE nr L 14 z dnia 20 stycznia $1998 \mathrm{r}$.

${ }^{27} \mathrm{~W}$ wyniku tej procedury zawarto umowy ramowe dotyczace telepracy oraz pracy związanej ze stresem.

${ }^{28}$ R. BLanpain, EU legislation on temporary work, [w:] Temporary Agency Work and Information Society, ed. R. Blanpain, R. Graham, cit., s. 250.

${ }^{29}$ A.M. ŚwiątKowski, Polityka społeczna i prawo pracy, «PiP» 57.7 (2002), s. 18. 
iż nie zdołali zawrzeć porozumienia w zakresie pracy tymczasowej. Przyczyną wstrzymania negocjacji podjętych w 2000 r. a przerwanych w 2001 r. był przede wszystkim brak porozumienia w kwestii pojęcia "pracownika porównywalnego". Na tle tego projektu pojawiły się rozbieżności w zakresie ustalenia, czy warunki zatrudnienia pracownika tymczasowego należy porównywać i odnosić do warunków zatrudnienia pracownika agencji, czy też pracownika pracodawcy użytkownika. Ostatecznie partnerzy społeczni stwierdzili, iż nie są w stanie osiagnąć porozumienia $^{30 .}$

Przypominając historię dotychczasowych prac nad projektem dyrektywy w sprawie pracowników tymczasowych należy zauważyć, że Komisja Europejska przedstawiła projekt dyrektywy w dniu 20 marca 2002 roku $^{31}$. W ramach projektu uwzględniono przyjęte przez europejskich partnerów społecznych kwestie. Uwzględniając opinię Parlamentu Europejskiego z 21 listopada 2002 roku Komisja Europejska w dniu 28 listopada 2002 roku przyjęła zmodyfikowaną propozycję dyrektywy ${ }^{32}$. Prace nad projektem zostały jednak zawieszone w październiku 2004 roku. Projekt przyjęty przez Komisję 20 marca 2002 r. został jednak ostatecznie wstrzymany w dniu 27 września $2005 r^{33}$

Biorąc pod uwagę trudności we wprowadzeniu regulacji pracy tymczasowej należałoby zastanowić się nad przyczynami kolejnych niepowodzeń. Komisja Europejska podejmując decyzję o odłożeniu prac nad projektem dyrektywy nie podała konkretnego terminu podjęcia na nowo negocjacji. Za jedną z głównych przyczyn nie wprowadzenia regulacji pracy tymczasowej na szczeblu wspólnotowym można uznać różnorodne regulacje tej instytucji w prawie poszczególnych państw członkowskich. Największym zainteresowaniem cieszy się obecnie

${ }^{30}$ D. MakowsKi, Zatrudnianie pracowników poprzez agencje pracy tymczasowej w świetle prawa wspólnotowego, «PiZS» $2003 \mathrm{nr} 7$, s. 15.

${ }^{31}$ COM (2002) 149 final.

${ }^{32}$ COM (2002) 701 final.

${ }^{33}$ P. KorzyŃski, Przyczyny wstrzymania projektu dyrektywy w sprawie pracowników tymczasowych, «PiZS» 2005 nr 11, s. 8. 
praca tymczasowa w czterech państwach członkowskich: Holandii, Francji, Niemczech i Wielkiej Brytanii. W prawie krajowym państw członkowskich regulacja pracy tymczasowej wygląda różnie. W doktrynie wyróżnia się dwa podejścia. W niektórych państwach członkowskich brak szczególnej regulacji pracy tymczasowej np. w prawie duńskim. Drugie podejście polega na wprowadzeniu ogólnej lub szczegółowej regulacji. Ten model dominuje w takich państwach jak: Niemcy, Francja, Belgia, Hiszpania, Holandia. Do niedawna wyróżniano także grupę państw zakazujących działania agencji pracy tymczasowej (np. Hiszpania, Włochy) ${ }^{34}$.

\section{OBECNY PROJEKT DYREKTYWY W ZAKRESIE ZATRUDNIANIA} PRACOWNIKÓW TYMCZASOWYCH

We wrześniu 2007 roku podjęto na nowo pracę nad zmienionym projektem dyrektywy Parlamentu Europejskiego i Rady w sprawie warunków pracy pracowników tymczasowych z dnia 28 lipca 2002 roku $^{35}$. Wprowadzenie regulacji wspólnotowej stało się konieczne także z uwagi na to, iż w ostatnim czasie liczba pracowników tymczasowych istotnie wzrosła ${ }^{36}$. Wzrost znaczenia pracy tymczasowej został spowodowany potrzebą zapewnienia elastyczności w zatrudnieniu. Praca tymczasowa stanowi również możliwość uzyskania zatrudnienia przez grupy, które doznają na rynku pracy szczególnych trudności w zakresie poszukiwania zatrudnienia, zwłaszcza dotyczy to ludzi młodych, kobiet, osób starszych, a także niepełnosprawnych ${ }^{37}$. Z dokumentów unijnych wyłania się wizja zbudowania w przyszłości społeczeństwa aktywnego, a nie społeczeństwa dwoistego. Społeczeństwo

${ }^{34}$ D. MakowsKI, Zatrudnienie pracowników tymczasowych, «PiZS» $2003 \mathrm{nr} 12$, s. 25 .

${ }^{35}$ COM 2002 (701) final.

${ }^{36}$ Por. J. Burges, J. Connell, International aspects of temporary agency employment: an overview, [w:] International Perspectives on Temporary Agency Work, London 2004, s. 18.

${ }^{37}$ P. KorzYŃSKI, Przyczyny wstrzymania projektu dyrektywy, cit., s. 8. 
aktywne to takie, w którym każdy zdolny do pracy i chcący pracować będzie mógł podjać pracę. Ponadto, promocja nietypowych form zatrudnienia, w tym pracy tymczasowej, wiąże się z budową społeczeństwa opartego na wiedzy. W sektorze technologii informatycznych widoczna jest potrzeba zatrudnienia pracowników o wysokich kwalifikacjach w tym zakresie. W praktyce coraz częściej przedsiębiorstwa zajmujące się najnowocześniejszymi technologiami korzystają z usług agencji pracy tymczasowej ${ }^{38}$.

Wśród celów wprowadzenia unormowania wskazano: konieczność wzmocnienia ochrony gwarantowanej pracownikom tymczasowym oraz poprawę jakości ich pracy poprzez zapewnienie realizacji zasady niedyskryminacji oraz pracowniczej podstawy zatrudnienia pracownikowi tymczasowemu ${ }^{39}$. W dokumencie podkreślano, iż konieczne jest osiągniecie równowagi pomiędzy ochroną pracowników tymczasowych a rolą odgrywaną przez agencję pracy tymczasowej na rynku pracy. Wprowadzenie odpowiedniej regulacji ma przyczynić się do stworzenia nowych miejsc pracy oraz płynności rynku pracy.

W projekcie Komisja Europejska podkreśliła, iż obowiązek wprowadzenia całościowego unormowania dotyczącego pracy tymczasowej wynika z przyjęcia przez państwa członkowskie obowiązku realizacji strategii lizbońskiej, której celem w zakresie polityki zatrudnienia jest stworzenie ,więcej pracy lepszej jakości” a docelowo osiagnięcie pełnego zatrudnienia. Ostatni projekt dyrektywy w zakresie pracy tymczasowej jest kontynuacją poprzednich wcześniej proponowanych rozwiązań.

Przede wszystkim jednak zauważyć należy, że zmieniono tytuł dyrektywy. Obecnie projekt został zatytułowany projektem dyrektywy w sprawie pracy tymczasowej, a nie jak poprzednio w sprawie warunków pracy pracowników tymczasowych. Z zaproponowanej zmiany może wynikać, iż projektem unormowania zostaną objęci poza

${ }^{38}$ R. BlanPain, op. cit., s. 263-263.

${ }^{39}$ Por. J. Arrowmith, Temporary agency work in enlarged European Union, European Foundation for the Improvement of Living and Working Condition, Dublin 2006, s. 1. 
pracownikami tymczasowymi inni uczestnicy pracy tymczasowej w większym zakresie niż dotychczas. Do projektu dyrektywy zostały wprowadzone liczne poprawki w trakcie negocjacji. Pierwsza naczelna zasada prawa wspólnotowego w zaproponowanym projekcie dotyczy identyfikacji pracodawcy w trójstronnym zatrudnieniu tymczasowych. Za pracodawcę ustawodawca wspólnotowy uznaje wyłącznie agencję pracy tymczasowej, a celem dyrektywy jest zapewnienie agencji pracy tymczasowej rozpoznawalnego statusu pracodawcy pracownika tymczasowego ${ }^{40}$. Warto zwrócić uwagę, iż no to, iż wprowadzenie projektowanej dyrektywy umożliwi właśnie rozpoznanie agencji pracy tymczasowej jako pracodawcę w trójstronnym zatrudnieniu tymczasowym. Ustawodawca wspólnotowy już wcześniej wskazywał, iż to do agencji pracy tymczasowej należy status pracodawcy a nie do podmiotu korzystającego $\mathrm{z}$ pracy pracownika tymczasowego w definicji pracy tymczasowej zawartej w dyrektywie 91/383/EWG dotyczącej bezpieczeństwa i ochrony zdrowia w miejscu pracy pracowników zatrudnionych na czas określony lub poprzez agencję pracy tymczasowej. Agencja pracy tymczasowej w myśl definicji zawartej w art. 3 projektu dyrektywy to podmiot zawierający umowę o pracę lub stosunek pracy z pracownikiem tymczasowym w celu skierowania go do wykonywania pracy pod kierownictwem pracodawcy użytkownika. Projekt dyrektywy w art. 3 definiuje także pojęcie pracownika tymczasowego oraz pojecie pracodawcy użytkownika. Pracownik tymczasowy to osoba związana umową o pracę lub stosunkiem pracy z agencją pracy tymczasowej z możliwością skierowania do pracodawcy użytkownika w celu wykonywania pracy tymczasowej pod jego kierownictwem. Pracodawca użytkownik to jakakolwiek osoba fizyczna lub prawna, na której rzecz i pod kierownictwem której wykonywana jest praca tymczasowa. Projekt dyrektywy definiuje także pojęcie „okres wykonywania pracy tymczasowej” jako czasu określonego wykonywania pracy pod kierownictwem pracodawcy użytkownika

Zgodnie z art. 1 projektu dyrektywa ma zastosowanie do umowy o pracę lub stosunku pracy pomiędzy agencją pracy tymczasowej

${ }^{40}$ R. Blanpain, op. cit., s. 249. 
a pracownikiem tymczasowym, który jest kierowany do pracy u pracodawcy użytkownika. Dyrektywę stosuje się do zarówno podmiotów publicznych, jak i prywatnych prowadzących działalność gospodarczą bez względu na to czy ich działalność nastawiona jest na osiagnięcie zysku czy nie.

Według projektu dyrektywy zakazy i ograniczenia w zakresie stosowania pracy tymczasowej są usprawiedliwione jedynie interesem ogólnym odnoszącym się do ochrony pracowników tymczasowych, wymogów bezpieczeństwa i higieny pracy oraz upewnienia się, że rynek pracy działa właściwie i zapobiega nadużyciom (art. 4 ust. 2 projektu). Wszelkie nieusprawiedliwione ograniczenia i zakazy zawarte w prawie krajowym należy znieść. Unormowanie to nie wpływa jednak na wymogi krajowe w zakresie rejestracji, licencjonowania, certyfikacji, gwarancji finansowych i monitorowania agencji pracy tymczasowej.

Wyłączenie stosowania dyrektywy nie będzie dopuszczalne tylko dlatego, że pracownik jest zatrudniony w niepełnym wymiarze czasu pracy lub na czas określony(art. 3 ust. 2). Warto zauważyć, że dyrektywa dotycząca pracy na czas określony nie dotyczy pracowników tymczasowych. Z zakresu zastosowania dyrektywy 99/70/WE ${ }^{41}$ dotyczącej pracy na czas określony wyłączono pracę tymczasową. Należy zaznaczyć, że projekt dyrektywy dotyczący pracy tymczasowej nie wskazuje wyraźnie rodzaju umowy o pracę, na podstawie której zatrudnia się pracownika tymczasowego. W prawie krajowym jako podstawa zatrudnienia pracownika tymczasowego może zostać wskazana umowa terminowa bądź umowa bezterminowa.

Wśród ważnych postanowień dyrektywy należy wskazać unormowanie w zakresie zasady równego traktowania pracowników tymczasowych, która stała się przyczyną wstrzymania prac nad projektem dyrektywy wobec braku zgody wszystkich państw członkowskich. W części wstępnej czytamy, że warunki pracy pracowników tymcza-

${ }^{41}$ Dyrektywa Rady 99/70/WE z dnia 28 czerwca 1999 r. dotycząca porozumienia ramowego w sprawie pracy na czas określony, Dz.Urz. WE nr L 175 z 10 lipca 1999 r., s. 43 . 
sowych w okresie skierowania do pracy tymczasowej u pracodawcy użytkownika powinny być co najmniej takie jak warunki pracy pracowników pracodawcy użytkownika (pkt 15, art. 5 ust. 1). Kolejny punkt stanowi, że w przypadku zatrudnienia pracownika tymczasowego na podstawie umowy bezterminowej moga istnieć jednak pewne wyjątki od zasad stosowanych u pracodawcy użytkownika z uwagi na większa stabilizację zatrudnienia w ramach tej podstawy prawnej. Dotychczas w dokumentach UE podkreślano, iż powszechną podstawą zatrudnienia pracownika jest umowa o pracę na czas nieokreślony. W przypadku zatrudnienia pracownika tymczasowego na podstawie umowy o pracę na czas nieokreślony postanowiono wprowadzić w pewnym zakresie odstępstwo.

Według projektu podstawowe warunki zatrudnienia dotyczą czasu pracy, pracy w godzinach nadliczbowych, przerw w pracy, okresów odpoczynku, pracy nocnej, płatnych urlopów i dni wolnych od pracy oraz wynagrodzenia (art. 3 pkt f). Projekt dyrektywy nie narusza definicji pojęć pracownik i wynagrodzenie i tym samym odsyła do prawa krajowego. Jednakże przepisy obowiązujące u pracodawcy użytkownika dotyczące ochrony kobiet w ciąży, matek karmiących piersią, dzieci oraz młodocianych, a także dotyczące równego traktowania kobiet i mężczyzn oraz każdego działania podejmowanego w celu zwalczania jakiejkolwiek dyskryminacji w zakresie płci, rasy lub pochodzenia etnicznego, religii, przekonań, niepełnosprawności, wieku lub orientacji seksualnej powinny być przestrzegane zgodnie z obowiązującym prawem.

W projekcie dyrektywy przewiduje się wyłączenia od zasady równego traktowania w zatrudnieniu pracownika tymczasowego. Wyłączenie zasady równego traktowania w zakresie wynagrodzenia będzie możliwe w prawie krajowym po konsultacji z partnerami społecznymi przy zatrudnieniu pracownika tymczasowego na podstawie umowy o pracę na czas nieokreślony, jeżeli pracownicy są wynagradzani w okresach niewykonywania pracy (art. 5 ust. 2). Nadto, partnerzy społeczni będą mogli zawrzeć odpowiednie porozumienie w zakresie stosowania zasady równego traktowania w odniesieniu do pracownika tymczasowego. Państwo członkowskie po konsultacji z partnerami społeczny- 
mi może dopuścić możliwość zawarcia porozumień zbiorowych, które zmniejszą zakres zasady równego traktowania w odniesieniu do pracowników tymczasowych przy zachowaniu odpowiedniego poziomu ochrony (art. 5 ust. 3). Państwa członkowskie mogą także ustalić, że zasada równego traktowania w zakresie wynagrodzenia będzie wyłączona $\mathrm{w}$ odniesieniu do pracownika tymczasowego, który pracuje nad zadaniem lub serią zadań u pracodawcy użytkownika przy pracy, która ze względu na okres trwania lub jej charakter może być zakończona w okresie nieprzekrajacym sześciu tygodni (art. 5 ust. 4). Obecnie zrezygnowano $\mathrm{z}$ pojęcia pracownika porównywalnego ${ }^{42}$. Trzeba przypomnieć, iż projekt dyrektywy pomimo wprowadzenia odstępstw w zakresie zasady równego traktowania został zablokowany przez Wielką Brytanię, Danię, Niemcy, Irlandię, Polskę i Słowację w czasie poprzedniego okresu negocjacji nad nim ${ }^{43}$.

W projekcie dyrektywy widoczne jest przesłanie, zgodnie z którym praca tymczasowa to jedynie przejściową formą wykonywania pracy. Wykonywanie pracy w charakterze pracownika tymczasowego powinno być ograniczone w czasie i prowadzić do znalezienia stałego zatrudnienia o odpowiedniej dobrej jakości. W myśl art. 6 pracownicy tymczasowi powinni być informowani o wolnych miejscach pracy u pracodawcy użytkownika. Informacje o wolnych miejscach pracy u pracodawcy użytkownika powinny być ogólnie dostępne. Wszelkie klauzule mające na celu niezatrudnienie pracownika tymczasowego powinny zostać uznane za nieważne. Dopuszczalne jest natomiast zawarcie $\mathrm{w}$ umowie pomiędzy agencją pracy tymczasowej a pracodawcą użytkownikiem postanowień w zakresie opłat pracodawcy użytkownika za usługi agencji pracy tymczasowej w zakresie delegowania, rekrutacji i szkolenia pracowników. Wyłączone jest jednak pobie-

${ }^{42}$ W. BeIRnAert, Report on Negotiations of the European Social Partners Towards an EU- wide Collective Agreement on Temporary Agency Work, [w:] Temporary Agency Work and Information Society, ed. R. Blanpain, R. Graham, cit., s. 297.

${ }^{43}$ L.W. Mitlacher, J. Burgess, Temporary Agency Work in Germany and Australia: Contrasting Regulatory Regimes and Policy Challenges, «The International Journal of Comparative Labour Law and Industrial Relations» 23 (2007), s. 426. 
ranie opłat przez agencję pracy tymczasowej od pracowników tymczasowych w szczególności za skierowanie do pracy u pracodawcy użytkownika lub za zawarcie umowy o pracę z pracodawcą użytkownikiem po okresie wykonywania pracy na rzecz pracodawcy użytkownika. Dyrektywa przewiduje zapewnienie dostępu pracownikom tymczasowym do urządzeń socjalnych i usług zbiorowych pracodawcy użytkownika, w szczególności stołówki, opieki nad dziećmi, usług transportowych na takich samych zasadach jak pracownicy pracodawcy użytkownika, chyba że istnieją obiektywne powody przeciwko temu. Państwa członkowskie podejmą odpowiednie środki w celu poprawy dostępu pracowników tymczasowych do szkoleń w agencji nawet pomiędzy okresami zatrudnienia, a także do szkoleń skierowanych do pracowników pracodawcy użytkownika (art. 6 ust. 5).

Według projektu dyrektywy Państwa członkowskie powinny określić zasady wliczania pracowników tymczasowych do ogólnej liczby zatrudnianych pracowników przez agencję pracy tymczasowej w celu ustalenia progu, po przekroczeniu którego powinny zostać utworzone organy reprezentujące pracowników. Państwa członkowskie mogą określić także zasady wliczania pracowników tymczasowych do ogólnej liczby zatrudnianych przez pracodawcę użytkownika pracowników, od której uzależniona jest realizacja jego obowiązków (art. 7).

\section{Podsumowanie}

Podsumowując należy zaznaczyć, że polska ustawa w zakresie pracy tymczasowej była wzorowana na projekcie dyrektywy z 2002 roku i jest uznawana za przykład implementacji nieobowiązującego prawa wspólnotowego do prawa polskiego tzw. proces dostosowania prawa polskiego „,z wyprzedzeniem”44. Należy podkreślić, że kształt polskiej regulacji w zakresie pracy tymczasowej jest uzależniony od kształtu prawa wspólnotowego. Dotychczas polskie unormowanie nie zostało

${ }^{44}$ L. FloreK, Zgodność polskiego prawa pracy z prawem europejskim, [w:] Europeizacja polskiego prawa pracy, red. W. SANETRA, Warszawa 2004, s. 32. 
znowelizowane pomimo zapowiedzi oceny ustawy po pierwszym roku jej obowiązywania i wprowadzenia zmian ${ }^{45}$.

$\mathrm{Na}$ gruncie polskiego prawa zasada równego traktowania pracowników tymczasowych obowiązuje bez wyjątków. Jeżeli projekt dyrektywy dotyczący pracy tymczasowej zostanie wprowadzony ustawodawca polski będzie musiał zdecydować czy pozostawić dotychczasowy stan prawny bez zmian czy też wprowadzić pewne odstępstwa od zasady równego traktowania w odniesieniu do pracowników tymczasowych. Sprzeciw Polski w negocjacjach nad projektem dyrektywy może oznaczać zapowiedź zmiany w zakresie polskiej regulacji pracy tymczasowej na niekorzyść pracownika tymczasowego. W obecnym kształcie polskie unormowanie w zakresie zasady równego traktowania można uznać za bardziej korzystne niż projektowane postanowienia prawa wspólnotowego.

Polskie unormowanie nie przewiduje unormowania w zakresie reprezentacji pracowniczej pracownika tymczasowego. Przede wszystkim ze wszystkim konsekwencjami w prawie polskim pracodawcą pracownika tymczasowego uznano agencję pracy tymczasowej. Oznacza to także konieczność realizowania przez agencje pracy tymczasowej obowiązków z zakresu zbiorowego prawa pracy uzależnionych od liczby zatrudnianych pracowników np. obowiązek wprowadzenia regulaminu pracy, regulaminu wynagradzania. Natomiast w świetle prawa polskiego pracownicy tymczasowi nie są brani pod uwagę przy ocenie stanu zatrudnienia pracodawcy użytkownika z uwagi na brak statusu pracodawcy tego podmiotu w relacji do pracownika tymczasowego.

Należy zauważyć, iż projekt dyrektywy nie odnosi sie do podstawy zatrudnienia pracownika tymczasowego. Państwa członkowskie będą mogły samodzielnie zdecydować o tym czy pracownik tymczasowy będzie zatrudniony na podstawie umowy o pracę na czas okre-

${ }^{45}$ Dotychczas zmianywprowadzonow zakresie obowiązkupracodawcyużytkownika zapewnienia pracownikowi tymczasowemu bezpiecznych i higienicznych warunków pracy, por. A. REDA, Nowe rozwiqzania ustawowe w zakresie obowiqzków pracodawcy użytkownika zapewnienia pracownikowi tymczasowemu bezpiecznych i higienicznych warunków pracy, «Monitor Prawa Pracy» 2007 nr 11, s. 577. 
ślony czy też na podstawie umowy o pracę na czas nieokreślony. Warto też podkreślić bardziej stanowcze podejście ustawodawcy unijnego do problemu identyfikacji pracodawcy w trójstronnym zatrudnieniu tymczasowym. Z projektu dyrektywy wynika jednoznacznie, iż to agencja pracy tymczasowej jest pracodawca pracownika tymczasowego. Jednakże agencja ma pełnić ten statusu tylko przejściową do czasu zatrudnienia pracownika tymczasowego przez pracodawcę użytkownika.

Proces prac nad wprowadzeniem całościowego unormowania w zakresie pracy tymczasowej przebiegał dotychczas burzliwie i bez większych sukcesów. Być może działania zapoczątkowane przezPrezydencję portugalską będą bardziej efektywne. Praca tymczasowa stanowi zjawisko o kontrowersyjnym oddźwięku. Wprowadzaniu unormowania w zakresie pracy tymczasowej towarzyszyły zawsze wątpliwości i liczne spory. Wystarczy wskazać przykład unormowania w zakresie pracy tymczasowej przez Międzynarodową Organizację Pracy, której dopiero niedawno udało się wprowadzić Konwencję Nr 181/1997 r. Stanowisko Międzynarodowej Organizacji Pracy w zakresie regulacji funkcjonowania płatnych biur pośrednictwa pracy w prawie międzynarodowym przeszło ewolucję od dążenia do ich likwidacji na początku XX w do zaakceptowania ich działalności pod koniec XX w. ${ }^{46}$

\section{Temporary Agency Work in EU Legislation}

\section{Summary}

The article is about the history of the temporary agency work in EU Legislation. The temporary agency work is an increasingly significant form of employment It involves a triangular arrangement in which an agency intermediates between the worker and the user enterprise in arranging

${ }^{46}$ Por. Z. HAJN, Regulacja prawna funkcjonowania prywatnych agencji zatrudnienia w prawie międzynarodowym i europejskim, «Studia Prawno-Europejskie» 5 (2001), s. 61 . 
temporary employment assignments. The regulation of temporary work in the European Union has been contentious for over twenty yearssince the Commission first proposed a directive in in 1982. The negotiations of the European Social Partners towards an EU - wide Collective Agreement on temporary work were broken down in 2002. The adoption was never immediate. There is only one directive in EU, adopted in 1991 which concerns temporary work and fixed term contracts and deals with the safety at work (Directive 91/383 of 25 June 1991). The article attempts to shows the main causes for establishing a suitable framework for temporary workers in the EU and the reasons for ceasing the Directive Project in 2002. The author also analyses the most important issues of the proposal of a Directive: equal treatment of temporary workers, collective representation, training and development opportunities. It is also an actual issue at the moment because the Portugal Presidency started working on the project of a directive concerning temporary work in 2007. 